\title{
Phosphate Fixation and P Mineralogy on Natural and Ca-Modified Zeolites During Simultaneous Nutrient Removal
}

\author{
Kristina Stocker ${ }^{\mathbb{D}} \cdot$ Markus Ellersdorfer
}

Received: 9 September 2021 / Accepted: 14 January 2022 / Published online: 25 January 2022

(C) The Author(s) 2022

\begin{abstract}
The recovery and recycling of nutrients $(\mathrm{N} \& \mathrm{P})$ from wastewater are one of the major topics to save primary energy and resources, to raise the efficiency of wastewater treatment plants, and to foster a future circular economy. In the present study, the removal of ammonium $\left(\mathrm{NH}_{4}{ }^{+}\right)$and phosphate $\left(\mathrm{PO}_{4}{ }^{3-}\right)$ using natural and Ca-treated zeolite is investigated in detail. Special emphasis is put on the simultaneous removal of both species from model solutions followed by elaborate mineralogical analyses (XRD, EPMA, FEG-SEM) for zeolite characterization and in order to determine the type, structure, and crystal sizes of CaP-phases precipitating on the zeolites surface. The effectivity of the phosphate segregation and chemical composition and the crystalline structure of the CaP-phase precipitating on the surface of the zeolite depend on the physico chemical conditions in particular on $\mathrm{pH}$, molar ratio of $\mathrm{Ca}$ and $\mathrm{P}$ (due to zeolite modification), and the presence of $\mathrm{NH}_{4}{ }^{+}$. Results of simultaneous removal experiments of N\&P revealed that $\mathrm{Ca}$ pretreatment enhances $\mathrm{P}$ segregation and increases the obtainable P-loadings of Ca-zeolites. Maximum P-loadings of $25 \mathrm{mg} \mathrm{g}^{-1} \mathrm{Ca}$-zeolite in binary solutions containing both ammonium and phosphate were obtained. Simultaneous phosphate
\end{abstract}

K. Stocker $(\bowtie) \cdot$ M. Ellersdorfer

Montanuniversität Leoben, Chair of Process Technology

and Industrial Environmental Protection, Franz Josef

Straße 18, 8700 Leoben, Austria

e-mail: kristina.stocker@unileoben.ac.at removal by surface precipitation of CaP-phases does not significantly influence ammonium ion exchange and the type of CaP-precipitates formed on the zeolite surface is assumed to be mainly brushite and apatite.

Keywords Surface precipitation - Ammonium removal $\cdot$ Clinoptilolite $\cdot$ Wastewater treatment

\section{Introduction}

In the actual discussions of promoting renewable energy, biogas and sewage treatment plants try to enhance their capacity for anaerobic digestion to produce green fuels (e.g., biomethane). This leads to increasing amounts of liquid digestates and sludge liquor, which contain ascending concentrations of dissolved ammonium and phosphorous due to intensified co-substrate fermentation. Legal regulations (maximum permissible values) and technological issues (ammonium inhibition) necessitate the reduction of both dissolved species by certain wastewater treatment methods. Nowadays, $\mathrm{NH}_{4}{ }^{+}$and $\mathrm{PO}_{4}{ }^{3-}$ are usually removed separately by biological and chemical processes. All of these standard processes are expensive and do not offer the possibility to recover, concentrate, and utilize $\mathrm{NH}_{4}{ }^{+}$and $\mathrm{PO}_{4}{ }^{3-}$ for example as nutrients in fertilizers. In contrast to these enormous amounts of $\mathrm{N}$ and $\mathrm{P}$ that are lost via global wastewater treatment systems, the food supply of an 
increasing world population strongly depends on the availability of these nutrients for crop cultivation.

Phosphorous is one of the building blocks of life and essential for many cellular processes and DNA synthesis. Additionally, no chemical component can substitute $\mathrm{P}$ in the life cycle and therefore $\mathrm{P}$ is irreplaceable (Cordell et al., 2009). By now, nearly three times the amount of the natural $\mathrm{P}$ cycle is mined per year from phosphate rock for anthropogenic needs (e.g., for fertilizer in agriculture and chemical and pharmaceutical products) (Vučić et al., 2021). In this human-affected cycle, $\mathrm{P}$ is lost at all stages of the processing systems (Daneshgar et al., 2018). After Kok et al. (2018); $3.7 \mathrm{Mt} \mathrm{a}^{-1}$ of $\mathrm{P}$ deriving from food is discarded via wastewater, where it is currently lost.

A similar picture can be observed for nitrogen, but even at a larger scale: since the invention of the Haber Bosch process in the beginning of the twentieth century, which enables the synthesis of $\mathrm{NH}_{3}$ from natural gas and atmospheric $\mathrm{N}_{2}$, nitrogen is extensively used as fertilizer. The global nitrogen cycle accounts for $\sim 400 \mathrm{Mt} \mathrm{a}^{-1}$, with approximately $50 \%$ thereof deriving from anthropogenic activities (Fowler et al., 2013).

Given these values, the recovery and utilization of $\mathrm{NH}_{4}^{+}$and $\mathrm{PO}_{4}{ }^{3-}$ are of great interest considering sustainability and closing of material cycles. As phosphorous is also one of the critical raw materials identified by the EU (European Commission, 2014), its recovery would contribute to a sustainable raw material supply. Currently, many countries throughout Europe promote the use of secondary phosphates (e.g., Switzerland and Germany) by making P-recovery mandatory for wastewater treatment plants that exceed defined sizes, e.g., > 50,000 population equivalent in Germany (Bundesministerium für Umwelt, Naturschutz und nukleare Sicherheit (BMU), 2017). Sweden and Austria are on the same path and committed themselves to put P-recovery into national legislation in the near future. Potential technologies for P-recovery comprise the precipitation of dissolved $\mathrm{PO}_{4}{ }^{3-}$ from the liquid phase as magnesium ammonium phosphates (MAP) or MAP/calcium phosphate minerals (Law \& Pagilla, 2018) as well as recovery from sewage sludge ash after incineration. The latter approach has some serious constraints like the costly technological facilities needed for monocombustion, storage and ash processing, and the production of certain amounts of (toxic) by-products. Hence, technologies for liquid phase recovery of $\mathrm{P}$ (and $\mathrm{N}$ ) are largely investigated, under which ion-exchange and adsorption processes on natural and modified zeolites have become an interesting topic (Yin \& Kong, 2014; Zhang et al., 2011). In contrast to synthetic zeolites, natural zeolites present an attractive option for applications in water purification due to their high abundance, availability, and low costs (Alshameri, Ibrahim, et al., 2014; Guaya et al., 2015b; Malekian et al., 2011; Zhang et al., 2011).

So far, natural zeolites have been rarely used for anion sorption due to the overall negative charge on their surface, caused by their crystal structure (Jiang et al., 2013). For anion and especially phosphate removal, modification of the surface of the zeolite is necessary. This is usually done by incorporation or impregnation of metal oxides and hydroxides in the zeolite pore structure (e.g., $\mathrm{Fe}, \mathrm{Al}, \mathrm{La}$, and other rare earth elements; Alshameri, Yan, et al., 2014; Jiménez-Cedillo et al., 2011; Sang et al., 2020; Simsek et al., 2013), the replacement of natural cations by the aforementioned metal ions via selective ion exchange (Guaya et al., 2015b), or the use of special, metalincorporated zeolites synthesized from fly ashes (e.g., Hermassi et al., 2020; Xu et al., 2022). The process of phosphate removal is usually related to surface precipitation of various insoluble chemical species, like monodentate and bidentate complexes on incorporated iron hydroxides inside the zeolite micropores (Guaya et al., 2015b).

Several studies have been conducted for the simultaneous removal of $\mathrm{NH}_{4}{ }^{+}$and $\mathrm{PO}_{4}{ }^{3-}$ from aqueous solutions by modified zeolites; many of them are based on synthetic zeolites, fly-ash zeolites, or mixtures of reactive sorbents (e.g., Gao et al., 2018; He et al., 2016; Hermassi et al., 2018; Salam et al., 2021; Zhang et al., 2007). Guaya et al. (2015b) modified natural clinoptilolite with $\mathrm{Fe}(\mathrm{III})$-ions to promote the formation of hydroxyl groups $(\cong \mathrm{Fe}-\mathrm{OH})$. Although simultaneous removal of $\mathrm{NH}_{4}{ }^{+}$and $\mathrm{PO}_{4}{ }^{3-}$ was found to be possible, the $\mathrm{NH}_{4}^{+}$exchange capacity was slightly decreased by the competing ions and surface precipitation of various MAP and CaP- minerals (blocking of pores). Furthermore, Guaya et al. (2015a) studied adsorption on a natural zeolite modified with hydrated aluminum oxide and increased $\mathrm{PO}_{4}{ }^{3-}$ sorption from 0.6 to $7 \mathrm{mg}-\mathrm{P} \mathrm{g}^{-1}$ while $\mathrm{NH}_{4}{ }^{+}$ sorption capacity is slightly decreased from 33 to $30 \mathrm{mg}-\mathrm{N} \mathrm{g}^{-1}$. In both studies, recovery of phosphate 
was found to be possible, but a reduction of phosphate uptake after several regeneration cycles was observed (Guaya et al., 2015a). Other studies show that simultaneous removal of $\mathrm{NH}_{4}{ }^{+}$and $\mathrm{PO}_{4}{ }^{3-}$ with zeolites modified by $\mathrm{Fe}, \mathrm{Al}, \mathrm{Mn}$, and $\mathrm{La}$ is possible for simulated wastewaters (e.g., Li et al., 2005; Ning et al., 2008; Li et al., 2009 and Huo et al., 2012). Performance depends on the competing ions in the applied wastewater and the pre-treatment. Simultaneous recovery of nitrogen and phosphorus was achieved by natural zeolites from sludge fermentation liquid in a study of Wan et al. (2017). Regeneration of expended zeolites can be carried out by $\mathrm{H}_{2} \mathrm{SO}_{4}$ (e.g., Choi et al., 2014) or NaOH-solutions (e.g., Guaya et al., 2015a). Generally, regeneration performance and products thereof depend on the type of zeolite surface modification and the phosphorous removal mechanism.

Some studies regarding P-removal with Ca-modified zeolites were published (e.g., Hermassi et al., 2016; Schick et al., 2012), but so far, Ca-modified zeolites were only rarely used for simultaneous N\&Premoval from different media. Sun et al. (2011) made sorption experiments with $\mathrm{CaCl}_{2}$-modified zeolite in aqueous solution. Phosphate removal efficiencies were $\mathrm{pH}$-dependent, with maximum values between 7 and 9. They stated that the mechanism of ammonium adsorption on the modified zeolite was ion exchange, whereas the removal of phosphate was a matter of chemical precipitation. You et al. (2017) investigated $\mathrm{Ca}-$ and $\mathrm{Mg}$-modified zeolites for the removal of $\mathrm{NH}_{4}{ }^{+}$and $\mathrm{PO}_{4}{ }^{3-}$ from simulated treated wastewater effluents. They measured maximum sorption capacities for a Ca-treated zeolite of $123.1 \pm 9 \mathrm{mg} \mathrm{NH}_{4}^{+} \mathrm{g}^{-1}$ and $119.5 \pm 7.5 \mathrm{mg} \mathrm{PO}_{4}{ }^{3-} \mathrm{g}^{-1}$ in an ammonium/phosphate binary system. Sorption mechanisms involved ammonium ion exchange and precipitation of $\mathrm{Ca}$ and $\mathrm{Mg}$ phosphates or mixed ammonium-magnesium phosphate minerals like apatite, brushite $\left(\mathrm{CaHPO}_{4}\right.$. $\left.\mathrm{H}_{2} \mathrm{O}\right)$, and struvite $\left(\mathrm{NH}_{4} \mathrm{MgPO}_{4} \cdot 6 \mathrm{H}_{2} \mathrm{O}\right)$. Mitrogiannis et al. (2017) reported that $\mathrm{Ca}(\mathrm{OH})_{2}$-treated zeolite can be effectively used for $\mathrm{PO}_{4}-\mathrm{P}$ removal from aqueous solutions under low $\mathrm{P}$ concentrations $(0.5-10 \mathrm{mg}$ $\mathrm{L}^{-1}$ ) with the predominant mechanisms for P-removal being ligand exchange and Ca-P surface precipitation. In subsequent studies, they applied $\mathrm{Ca}(\mathrm{OH})_{2}$-treated zeolites for P-removal from urine (Mitrogiannis et al., 2018) and olive mill wastewater (Mitrogiannis et al., 2020), where maximum P removals of 73.9 and $85.9 \%$ for two different wastewater samples were achieved.

The present study further investigates the phosphate removal via natural and Ca-modified zeolites (clinoptilolite) by applying an elaborate set of chemical and mineralogical analyses for the liquid solutions as well as the solid materials. The type of P-phases formed on the applied zeolites is further investigated and sorption capacities in binary aqueous solutions containing $\mathrm{NH}_{4}{ }^{+}$and $\mathrm{PO}_{4}{ }^{3-}$ are presented in order to improve simultaneous ammonium and phosphate removal and recovery from real effluents in the ILS process (Ellersdorfer, 2018) and other potential future applications.

\section{Materials and Methods}

Sorption experiments for single and simultaneous phosphate segregation were conducted using natural and Ca-modified natural zeolite. For Ca-modification, natural zeolite from Eastern Slovakia was treated with $\mathrm{CaCl}_{2}$ solution $(0.5 \mathrm{M}$; $\mathrm{pH} 10)$ for $24 \mathrm{~h}$ in columns using a volume of $20 \mathrm{~L}$ of treatment solution and $2.3 \mathrm{~kg}$ of natural zeolite (grain size $1.5-2 \mathrm{~mm}$ ). Diameter of the column was $120 \mathrm{~mm}$ and flow rate $2.5 \mathrm{~L} \mathrm{~min}^{-1}$. To ensure a complete submersion of the zeolite, the modification process was run in up flow mode. After modification, the zeolite was flushed with deionized water until $\mathrm{pH} 7$ was reached. The modified zeolite was dried at $105{ }^{\circ} \mathrm{C}$ and stored in hermetically sealed bottles until sorption experiments.

Screening and single phosphate sorption experiments were conducted in batch operation with dibasic sodium phosphate dodecahydrate solutions $\left(\mathrm{Na}_{3} \mathrm{PO}_{4} .12 \mathrm{H}_{2} \mathrm{O}\right)$ in a concentration range from 500 to $2500 \mathrm{mg} \mathrm{PO}_{4}{ }^{3-} \mathrm{L}^{-1}$. For preliminary screening experiments, a concentration of $2500 \mathrm{mg} \mathrm{PO}_{4}{ }^{3-} \mathrm{L}^{-1}$ was used. For simultaneous sorption from binary solutions (N\&P), an additional amount of $1000 \mathrm{mg}$ $\mathrm{L}^{-1}$ of $\mathrm{NH}_{4}^{+}$was added to each phosphate solution using ammonium sulfate $\left.\left(\left(\mathrm{NH}_{4}\right)_{2} \mathrm{SO}_{4}\right)\right)$. If necessary, $\mathrm{pH}$-values were adjusted with sulfuric acid $\left(\mathrm{H}_{2} \mathrm{SO}_{4}\right.$; 96\%). The batch system used for sorption experiments was the same for both experimental approaches: $500 \mathrm{~mL}$ of initial single/binary solution was treated with $20 \mathrm{~g}$ of natural and Ca-modified zeolite for $24 \mathrm{~h}$ in an overhead shaker at $20{ }^{\circ} \mathrm{C}$ respectively. In order 
to avoid abrasion of the material due to agitation, the zeolite was packed into cotton bags.

Liquid samples were taken before and after the sorption experiments and filtrated by syringe filters $(0.22 \mu \mathrm{m})$. Ammonium was detected via Kjeldahl method using boric acid and $\mathrm{HCl}(0.1 \mathrm{M})$ /Tashiro's indicator for titration. For phosphate analysis, the photometer method was used (Merck Spectroquant ${ }^{\circledR}$ 114848). The difference in $\mathrm{PO}_{4}{ }^{3-}$ and $\mathrm{NH}_{4}{ }^{+}$concentration of the initial and final solution represents the amount of removed phosphate and ammonium and therefore the effective segregation capacity for different equilibrium concentrations which yields to the sorption isotherm under the given conditions.

For data interpretation, the equilibrium loadings $\left(q_{\mathrm{PO}_{4}^{3-}} / \mathrm{NH}_{4}^{+}\right)$were evaluated by the amount of adsorbed phosphate/ammonium per unit mass of zeolite (in $\mathrm{mg}$ $\mathrm{PO}_{4}{ }^{3-} \mathrm{g}^{-1}$ zeolite or $\mathrm{mg} \mathrm{NH}_{4}{ }^{+} \mathrm{g}^{-1}$ zeolite), calculated according to the following equation:

$q_{P O_{4}^{3-} / N H_{4}^{+}}=\frac{\left(C_{0}-C_{e}\right) \cdot V}{m}$

where $C_{0}$ and $C_{\mathrm{e}}$ are the phosphate/ammonium concentrations $\left(\mathrm{mg} \mathrm{L}^{-1}\right)$ of the stock solutions at initial and final stage of the experiment, $V$ is the total solution volume (L), and $m$ is the mass of the zeolite (g).

Mineralogical investigations were done before and after the modification step and at the end of the segregation experiments using dried samples $\left(105{ }^{\circ} \mathrm{C}\right)$, which were sealed in plastic containers and stored for subsequent solid analysis. The material was characterized by X-ray diffraction (XRD) as well as electron microprobe (EPMA) and scanning electron microscopy (FEG-SEM). XRD was conducted with a PANalytical X'Pert Pro, $\mathrm{Cu} \mathrm{K} \alpha, \lambda=1.541 \mathrm{~nm}$ at the Chair of Petroleum Geology, Montanuniversität Leoben. XRD patterns were evaluated with the software X'Pads with its attached ICDD databases. Electron micropobe technique was used for chemical mapping using a Superprobe Jeol JXA8200 instrument at the Eugen F. Stumpfl Microprobe Laboratory provided by UZAG at Montanuniversität Leoben. Element mappings were made from carbon-coated polished sections. Morphology and surface studies of the zeolite before and after the sorption experiments were undertaken using FEG-SEM technique (LEO 1525, Carl Zeiss SMT at Erich Schmid Institute of Material
Science, Leoben). Zeolite grains were sticked on a carbon tab placed on an aluminum stub and coated with a carbon layer. BSE high resolution microphotographs of the zeolite were taken at an acceleration voltage of $5 \mathrm{kV}$.

\section{Results and Discussion}

\subsection{Characterization of the Untreated and Treated} Raw Material

The XRD spectra represent the whole rock mineral composition of both the untreated and Ca-treated zeolitic rock (Fig. 1). The X-ray diffraction pattern of the untreated zeolite identifies a HEU-type zeolite (clinoptilolite) as the main mineralogical phase in the raw material. Minor phases include biotite (annite?), plagioclase (dominantly andesine), alkali feldspar, quartz, and cristobalite. Minor amounts of plagioclase and biotite differ slightly between the untreated and treated zeolite but do not indicate significant changes in the mineralogical composition of the different samples nor mineral transformation from pre-treatments (Vollprecht et al., 2019). The different cation loading after the treatment has no significant impact on the peak position of the clinoptilolite. A slight enhancement of the background signal between 20 and $30^{\circ} 2 \theta$ may indicate minor amounts of amorphous vulcanic glass (Ostrooumov et al., 2012).

The mean chemical composition $(n=22)$ of the clinoptilolite obtained by EPMA and the cations per formula units were calculated based on 72 oxygens, deriving from the ideal formulas of HEU type zeolites (Heulandite $(\mathrm{Na}, \mathrm{K}) \mathrm{Ca}_{4}\left(\mathrm{Al}_{8} \mathrm{Si}_{28}\right) \mathrm{O}_{72} .24 \mathrm{H}_{2} \mathrm{O}$ and clinoptilolite $\left.(\mathrm{Na}, \mathrm{K})_{6}\left(\mathrm{Al}_{6} \mathrm{Si}_{30}\right) \mathrm{O}_{72} .20 \mathrm{H}_{2} \mathrm{O}\right)$ and are listed in Table 1.

$\mathrm{Si}$ and $\mathrm{Al}$ are assigned to the tetrahedral site and $\mathrm{Na}, \mathrm{K}, \mathrm{Ca}$, and $\mathrm{Mg}$ to the exchangeable cation sites. Spots for the WDS analysis were selected using back scattered electron (BSE) images and EDS spectra, in order to avoid contamination by iron hydroxides and to distinguish minor minerals (quartz and feldspar) from the zeolite matrix.

\subsection{Sorption Experiments}

Results from preliminary screening experiments for phosphate segregation show that the $\mathrm{PO}_{4}{ }^{3-}$-loading 
on natural zeolite accounts for $12.3 \mathrm{mg} \mathrm{PO}_{4}{ }^{3-} \mathrm{g}^{-1}$ zeolite (Table 2). The $\mathrm{pH}$ value of the initial phosphate solution $\left(\sim 2500 \mathrm{mg} \mathrm{PO}_{4}{ }^{3-} \mathrm{L}^{-1}\right)$ slightly decreases from 12.23 to 11.93 after $24 \mathrm{~h}$ of contact with the natural zeolite sample. Adjustment of the $\mathrm{pH}$-value of the initial solution to 8.5 leads to a small increase of the phosphate removal capacity (14.5 $\mathrm{mg} \mathrm{PO}_{4}{ }^{3-} \mathrm{g}^{-1}$ ) and a larger decline in the $\mathrm{pH}$-value during $24 \mathrm{~h}$ of $\mathrm{PO}_{4}{ }^{3-}$-segregation (8.5 to 7.67 ) as a consequence of the logarithmic $\mathrm{pH}$-scale. Phosphate loading of
Ca-pretreated zeolite $\left(6.5 \mathrm{mg} \mathrm{PO}_{4}{ }^{3-} \mathrm{g}^{-1}\right)$ is only half of the loading of natural zeolite at high $\mathrm{pH}$-values $(\sim 12)$ but is more than doubled when the $\mathrm{pH}$-value is adjusted to values $<8$. With a value of $13.1 \mathrm{mg}$ $\mathrm{PO}_{4}{ }^{3-} \mathrm{g}^{-1}$, the final loading of Ca-pretreated zeolite after $24 \mathrm{~h}$ is higher than the value of untreated zeolite without $\mathrm{pH}$-adjustment. These results emphasize the importance of the $\mathrm{pH}$-value for phosphate removal by the formation of CaP-phases. In any of the conducted experiments, the $\mathrm{pH}$-value of the loading solution is

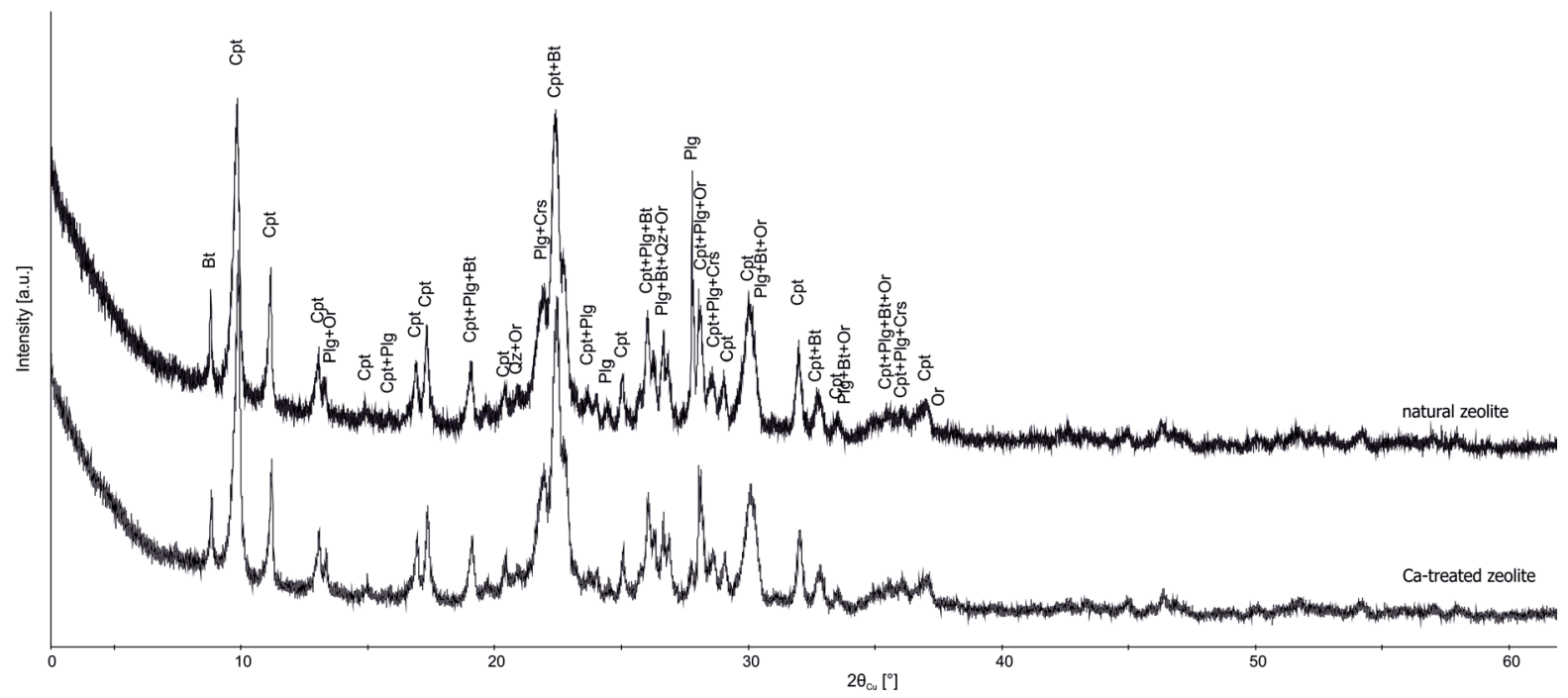

Fig. 1 X-ray diffraction (XRD) patterns of zeolites with different cation loading (bt: biotite, cpt: clinoptilolite, plg: plagioclase, qz: quartz, crs: cristobalite, or: orthoclase)

Table 1 Mean chemical composition of zeolite minerals obtained by EPMA (calculations based on 72 oxygen atoms, apfu atoms per formula unit)

\begin{tabular}{llllllll}
\hline & & $\mathrm{Si}$ & $\mathrm{Al}$ & $\mathrm{Na}$ & $\mathrm{K}$ & $\mathrm{Ca}$ & $\mathrm{Mg}$ \\
\hline & $n$ & {$[\mathrm{apfu}]$} & {$[\mathrm{apfu}]$} & {$[\mathrm{apfu}]$} & [apfu] & {$[\mathrm{apfu}]$} & {$[\mathrm{apfu}]$} \\
Natural zeolite & 22 & 30.53 & 5.93 & 0.08 & 0.44 & 1.61 & 0.14 \\
Ca-treated zeolite & 13 & 30.43 & 5.63 & 0.05 & 0.85 & 1.67 & 0.09 \\
\hline
\end{tabular}

Table 2 Phosphate segregation on natural and Ca-pretreated zeolites after $24 \mathrm{~h}$ of contact with model solutions $\left(2500 \mathrm{mg}^{\mathrm{PO}}{ }_{4}{ }^{3-}\right.$ $\mathrm{L}^{-1} ; \mathrm{Na}_{3} \mathrm{PO}_{4} .12 \mathrm{H}_{2} \mathrm{O}$ ) at different $\mathrm{pH}$-values

\begin{tabular}{|c|c|c|c|c|c|c|}
\hline Sample & $\mathrm{pH}_{(\mathrm{t}=0)}$ & $\mathrm{pH}_{(\mathrm{t}=24 \mathrm{~h})}$ & $\mathrm{PO}_{4}{ }^{3-}$-loading & $\mathrm{pH}_{(\mathrm{t}=0)}$ & $\mathrm{pH}_{(\mathrm{t}=24 \mathrm{~h})}$ & $\mathrm{PO}_{4}{ }^{3-}$-loading \\
\hline & {$[-]$} & {$[-]$} & {$\left[\mathrm{mg} \mathrm{PO}_{4}{ }^{3-} \mathrm{g}^{-1}\right]$} & {$[-]$} & {$[-]$} & {$\left[\mathrm{mg} \mathrm{PO}_{4}{ }^{3-} \mathrm{g}^{-1}\right]$} \\
\hline Natural zeolite & 12.23 & 11.93 & 12.3 & 8.5 & 7.67 & 14.5 \\
\hline Ca-treated zeolite & 12.23 & 12.00 & 6.5 & 7.37 & 7.02 & 13.1 \\
\hline
\end{tabular}


lower after phosphate segregation, which is a result of the acidic reactions responsible for the CaP-phase formation.

The single phosphate sorption experiments (Fig. 2; left) reveal a continuous increase of the phosphate loading with a maximum of around $20 \mathrm{mg} \mathrm{PO}_{4}{ }^{3-} \mathrm{g}^{-1}$ at initial solution concentrations of $2500 \mathrm{mg} \mathrm{PO}{ }_{4}^{3-} \mathrm{L}^{-1}$ for both natural and Ca-treated zeolites. Whereas natural zeolite P-loading is higher at solution concentrations $<250 \mathrm{mg} \mathrm{L}^{-1}$; Ca-treatment leads to higher phosphate removal capacities between 250 and $1000 \mathrm{mg} \mathrm{PO}_{4}{ }^{3-} \mathrm{L}^{-1}$. Nevertheless, the observed maximum P-loadings are similar, which may be an effect of the establishment of an equilibrium between the dissolved cations in the solution $\left(\right.$ mostly $\mathrm{Na}^{+}$) and the exchangeable ions on the zeolite (mainly $\mathrm{Ca}^{2+}$; Table 1 ), which is limited by the amount of available cations in the solution.

The addition of ammonium changes the phosphate sorption capacities of natural zeolite and leads to significantly higher P-loadings up to a concentration of $1000 \mathrm{mg} \mathrm{PO}_{4}{ }^{3-} \mathrm{L}^{-1}$ (Fig. 2; right). Nevertheless, the maximum P-loading of natural zeolite at $2500 \mathrm{mg}$ $\mathrm{PO}_{4}{ }^{3-} \mathrm{L}^{-1}$ in binary solution is similar to that of the single phosphate experiment $\left(\sim 20 \mathrm{mg} \mathrm{PO}_{4}{ }^{3-} \mathrm{g}^{-1}\right)$. The P-loadings of Ca-modified zeolite reveal significantly higher values over the whole concentration range with a maximum of $25 \mathrm{mg} \mathrm{PO}_{4}{ }^{3-} \mathrm{g}^{-1}$ at $2500 \mathrm{mg} \mathrm{PO}_{4}{ }^{3-} \mathrm{L}^{-1}$. These results indicate that the P-loading capacity of the natural zeolite is affected by Ca-limitation at higher P-concentration levels, where the natural zeolitic $\mathrm{Ca}^{2+}$-ions are already expended and the additional ammonium-ions in the loading solutions cannot deliberate extra Ca-ions. Ca pretreatment increases the available amounts of $\mathrm{Ca}^{2+}$ in the zeolite structure and cations like $\mathrm{NH}_{4}{ }^{+}$can mobilize these additional $\mathrm{Ca}$-ions in order to increase $\mathrm{Ca}$-phosphate precipitation.

Ammonium sorption for natural and Ca-treated zeolite is between 12 and $16 \mathrm{mg} \mathrm{NH}_{4}^{+} \mathrm{g}^{-1}$ and tends to increase slightly with rising $\mathrm{P}$-concentrations. As indicated by the similar values of $\mathrm{NH}_{4}{ }^{+}$-loading on both zeolites, the ammonium ion exchange is hardly influenced by the formation of CaP-phases, although a small decrease in the $\mathrm{NH}_{4}{ }^{+}$-loading can be observed for the maximum phosphate binding zeolite (Catreated zeolite at $2500 \mathrm{mg} \mathrm{L}^{-1} \mathrm{PO}_{4}{ }^{3-}$ ). In comparison to single ammonium sorption experiments $(1000 \mathrm{mg}$ $\mathrm{NH}_{4}{ }^{+} \mathrm{L}^{-1}$ without $\mathrm{PO}_{4}{ }^{3-}$-addition; dotted lines in Fig. 2), $\mathrm{NH}_{4}^{+}$-uptake during simultaneous operation is in the same range as in single ion exchange experiments, which is another proof that ammonium exchange is not negatively influenced by CaP-precipitation (e.g. blockage of pores).

\subsection{Identification of the Solid Phases After Precipitation}

Several different techniques were applied in order to identify the precipitated mineral phase on the zeolites surface. Observation with FEG-SEM technique gives information about the morphological aspects like crystal form, shape, size, and grade of crystallinity. Analyses with EPMA technique provided information
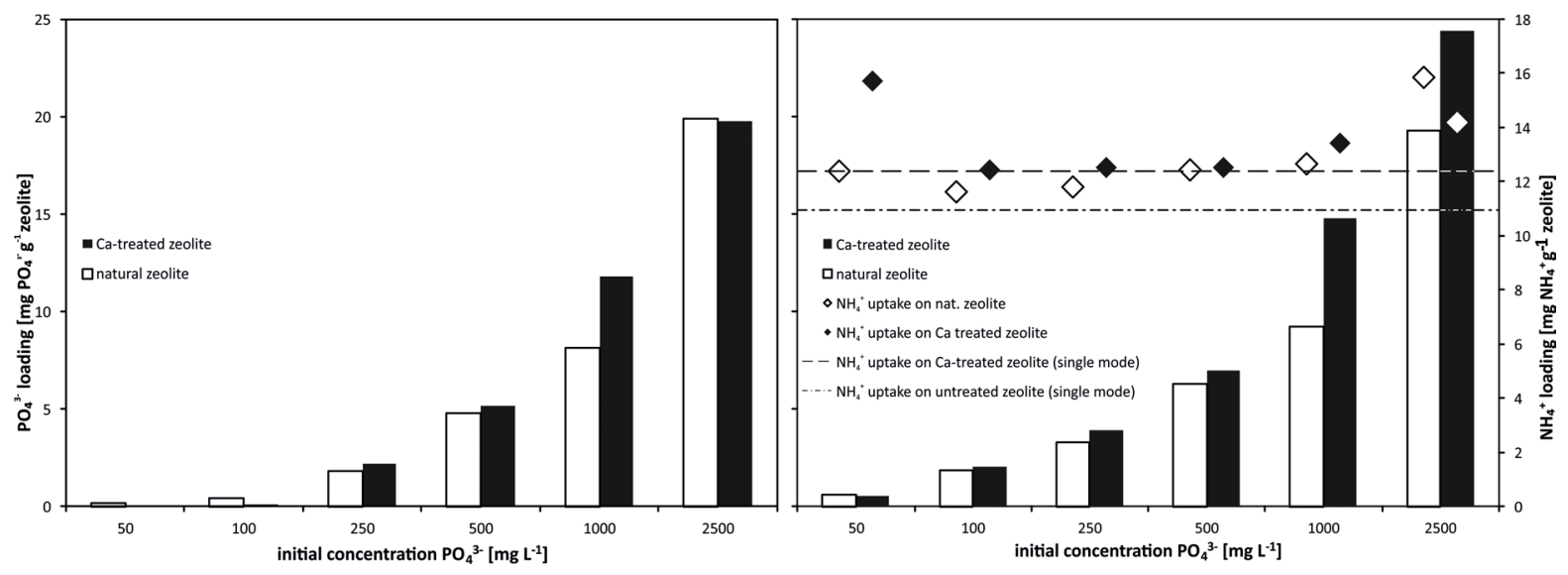

Fig. 2 Results of $\mathrm{P}$ (left) and N\&P-sorption experiments (right) as a function of initial $\mathrm{PO}_{4}{ }^{3-}$-concentrations in the solution 
about the chemical composition of the precipitate. The formation of the precipitates was observed only in $\mathrm{pH}$-adjusted solutions combined with the $\mathrm{Ca}$ treated zeolite.

A BSE image of the cross section after sorption experiments presented in Fig. 3 shows the typical texture of a zeolitic tuff as it was used in this study. Coarser grained, partially idiomorphic mineral phases are embedded in a finer grained matrix. The main different components distinguishable by different gray scales were identified by EDS and consist of clinoptilolite, plagioclase, K-Feldspar, and minor amounts of quartz and biotite. Clinoptilolite occurs thereby as distinct grains filling pore spaces, extremely finegrained matrix material, and clinoptilolite pseudomorphs of former glass shards representing its volcanic origin. This is consistent with the mineral composition obtained by XRD (Fig. 1).

Mapping of the elemental distribution by EPMA in the same area is shown in Fig. 4a-f. Aluminum and silicon are revealed in all regions of the zeolite grain as they are considered as the ions in the tetrahedral sites of zeolite crystal lattice. $\mathrm{K}, \mathrm{Na}$, and $\mathrm{Ca}$ as exchangeable cations of the zeolite are also distributed over the whole cross section. Distinct higher amounts of $\mathrm{Ca}, \mathrm{Na}$, and $\mathrm{Al}$ in some regions of the cross section can be explained by feldspar crystals which occur in the fine-grained matrix of the zeolite rock. High concentrations of calcium and phosphorous are less uniformly distributed. Notably, phosphorous is largely absent in the center of the grain but is enriched on the rim of the zeolite forming the precipitate together with calcium (Fig. 4e and f).

BSE pictures from polished cross sections obtained during EPMA in Fig. 5 reveal details of zeolite grains after precipitation at higher magnification; an accumulation of fine-grained CaP-phases especially in small cavities and niches along the rim of the zeolite grain is particularly visible and shows two different types of crystal shapes occurring as described in detail below.

Precipitates of calcium phosphate $(\mathrm{CaP})$ produced during $\mathrm{pH}$-adjusted screening experiments were observed using FEG-SEM technique following the protocol described in the "Materials and Methods" section. The CaP-crystals shown in Fig. 5 are representative of precipitates produced at $\mathrm{pH} 7$ during $24 \mathrm{~h}$ sorption from a $2500-\mathrm{mg} \mathrm{PO}_{4}{ }^{3-} \mathrm{L}^{-1}$ solution (Table 2). The experiments resulted in the formation of acicular crystals up to a grain size of $5 \mu \mathrm{m}$ (Fig. 6a-c) and platy, radiating rose-like aggregates of tabular crystals up to a size of $100 \mu \mathrm{m}$ (Fig. 6d-f). Due to crystal habit and crystal form, it can be assumed that these are tabular crystals of monoclinic
Fig. 3 Photomicrograph of a representative cross section of the zeolite obtained by EPMA showing rock fabric and mineral assemblage (bt: biotite, cpt: clinoptilolite, plg: plagioclase, qz: quartz, or: orthoclase)

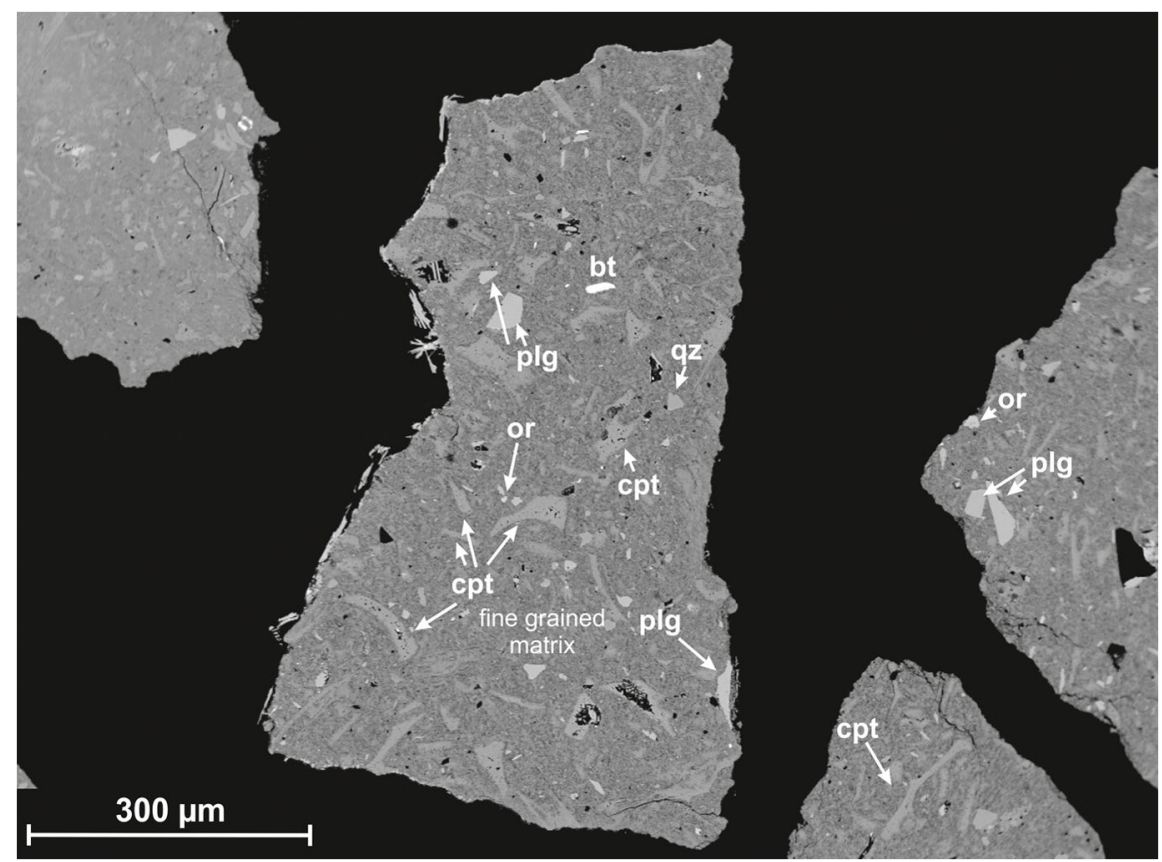


Fig. 4 a-f Elemental distribution obtained by EPMA of the cross section of a representative zeolite grain after sorption experiments with $2500 \mathrm{mg} \mathrm{L}^{-1} \mathrm{PO}_{4}{ }^{3-}$ for $24 \mathrm{~h}$ and adjusted $\mathrm{pH}$ to 7 : a silicon map, $\mathbf{b}$ aluminum map, $\mathbf{c}$ sodium map, $\mathbf{d}$ potassium map, e calcium map, and $\mathbf{f}$ phosphorous map; brighter regions correspond to higher amounts of the respective element
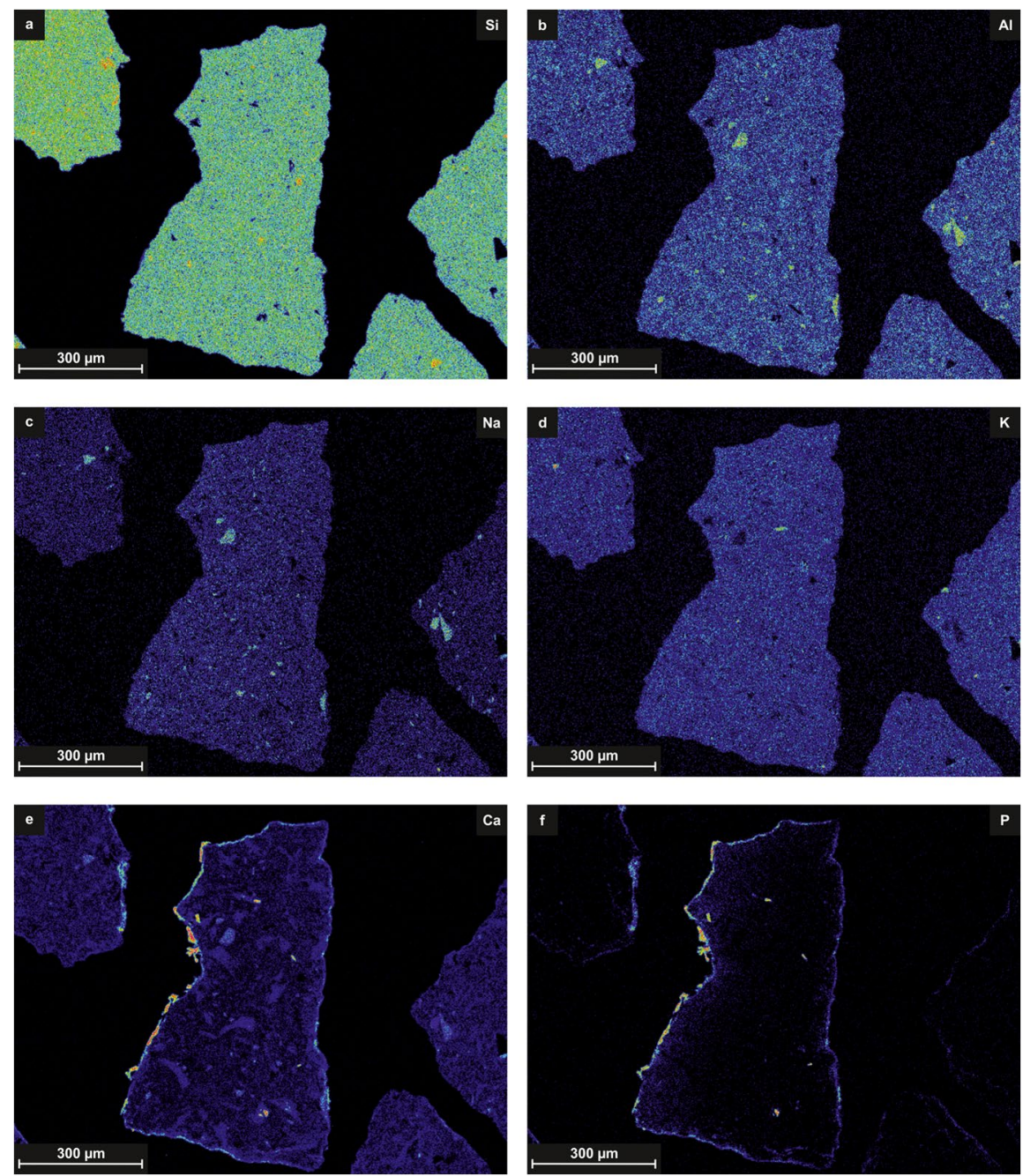

brushite with perfect cleavage in [001] and [010]. Besides, brushite acicular crystals, especially contact twinned, can also be assumed as hydroxylapatite.

In summary, the simultaneous removal of ammonium and phosphate is possible both with natural and Ca-modified zeolites. The applied method of $\mathrm{Ca}$ pretreatment with $\mathrm{CaCl}_{2}$-solutions, which increases the Ca-loading and subsequently also the P-removal efficiency, can be executed by simple immersion of the zeolite grains in liquid $\mathrm{CaCl}_{2}$-solutions without several ion-exchange stages (e.g., Guaya et al., 2015a, b) subsequent drying, calcination, or other (thermal) treatments. This is of specific interest for the further development of the ILS-process, where columns filled with zeolite grains $(1-3 \mathrm{~mm})$ together with sodium hydroxide solutions are used for ammonium removal via acid scrubbing. $\mathrm{CaCl}_{2}$-solutions can be applied for a simple in-line treatment of zeolite grains to remove phosphate from wastewater in a subsequent extra-column, which is loaded with $\mathrm{CaCl}_{2}$ and recovered by acid flushing from time to time. Hence, the ILS-process itself is not changed but only expanded by an additional column used for P-removal, which enables simultaneous removal but selective recovery of $\mathrm{N} \& \mathrm{P}$ in order to recycle these valuable nutrients. 
Fig. 5 a-f Detailed images of a cross-section of the CaP-coated zeolite and elemental distributions demonstrating the thickness and two different types of the $\mathrm{CaP}$ precipitates present on the zeolites surface; brighter regions correspond to higher amounts of the respective element
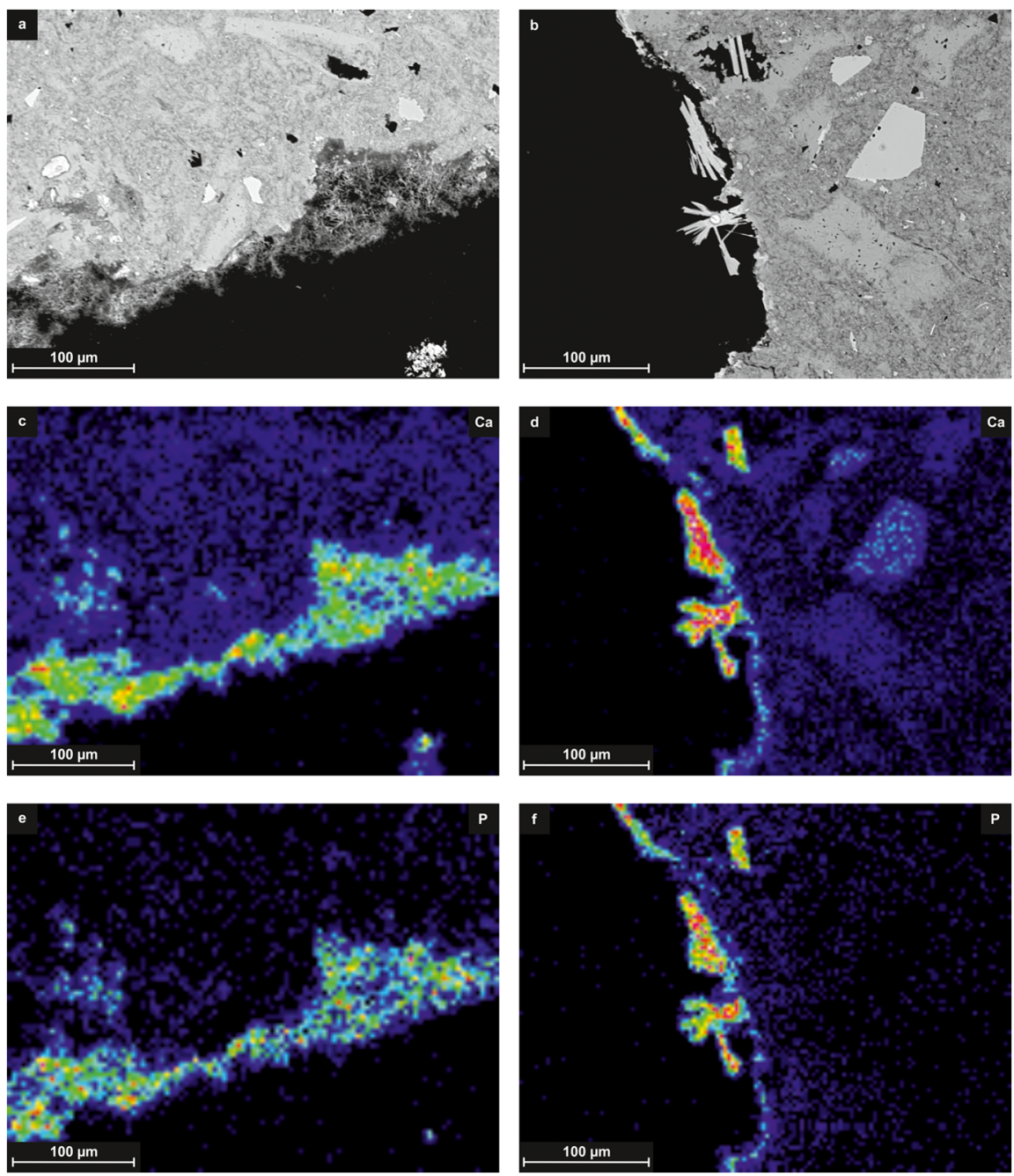

\section{Conclusions}

Results from the sorption experiments show that Ca-treated natural zeolite can be used to simultaneously remove ammonium and phosphate from aqueous solutions. Natural zeolitic calcium is exchanged with sodium ions in $\mathrm{Na}_{3} \mathrm{PO}_{4}$-solutions leading to the precipitation of free $\mathrm{PO}_{4}{ }^{3-}$ as CaP-phases on the zeolite. The same effect can be observed in presence of additional $\mathrm{NH}_{4}{ }^{+}$, which enhances CaP-precipitation due to higher cation concentrations and ammonium selectivity, which deliberates more Ca-ions, if they are available (Ca-treatment). For natural zeolites, Ca-limitation impedes CaP-precipitation at higher $\mathrm{PO}_{4}{ }^{3-}$-concentrations; wherefore, the following conclusions can be drawn:
- P segregation using zeolites is feasible and similar for natural and Ca-pretreated zeolites in phosphate solutions.

- $\mathrm{Ca}$ pretreatment enhances $\mathrm{P}$ segregation and increases the obtainable P-loadings of $\mathrm{Ca}$-zeolites.

- $\mathrm{P}$ segregation is higher in solutions containing additional $\mathrm{NH}_{4}^{+}$(binary solutions) for both natural zeolites and Ca-treated zeolites as long as natural zeolitic Ca-ions are sufficiently available.

- Ca-treatment significantly increases P-loadings in binary solutions with higher $\mathrm{PO}_{4}{ }^{3-}$ concentrations $\left(>100 \mathrm{mg} \mathrm{L}^{-1}\right)$ and maximum P-loadings of $25 \mathrm{mg} \mathrm{g}^{-1} \mathrm{Ca}$-zeolite were measured. 
Fig. 6 a-f Representative images of the CaP precipitates present on the surface of Ca-treated zeolite after the experimental approach in the study. Pictures a to c show acicular crystals growing on clinoptilolites crystals and pictures $\mathbf{d}$ and e show platy to tabular crystals of brushite(?), f: roselike aggregate of brushite(?) crystals
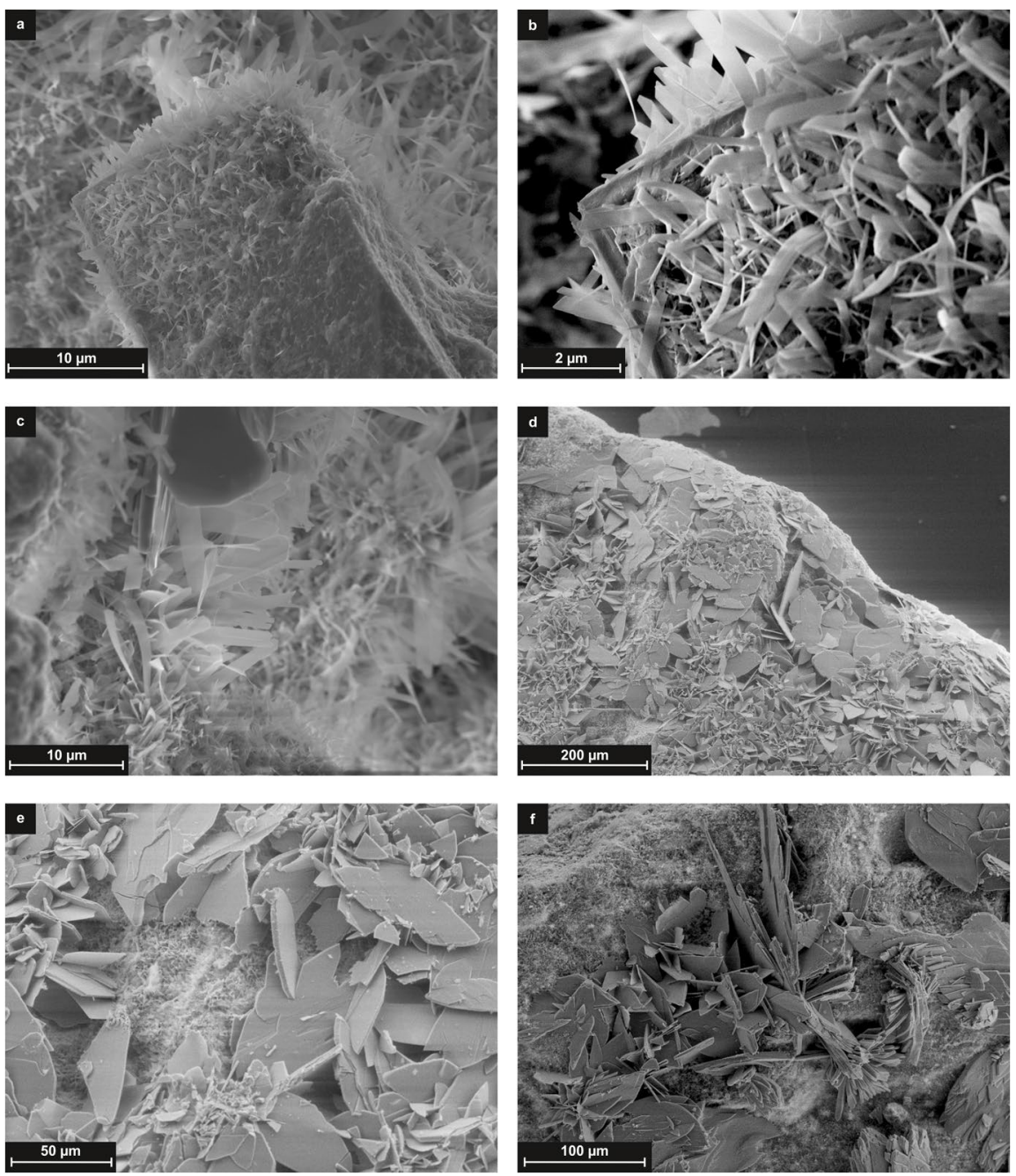

- CaP-phase formation does not significantly influence ammonium ion exchange in the experimental setup used for this study.

- The type of CaP-precipitates formed on the zeolites surface is assumed to be brushite and apatite.

This leads to the assumption that the natural $\mathrm{Ca}$ loading of the applied zeolite is not sufficient for a complete CaP-precipitation and P-loadings are limited by the available $\mathrm{Ca}$-cations in the zeolite structure. The effectivity of the phosphate segregation as well as the chemical composition and crystalline structure of the CaP-phases precipitating on the surface of the zeolite depends on the physicochemical conditions in particular on $\mathrm{pH}$, molar ratio of $\mathrm{Ca}$ and $\mathrm{P}$ (influenced by zeolite modification), and the presence of $\mathrm{NH}_{4}{ }^{+}$. For the effective recovery of phosphate from real effluents of wastewater treatment plants, $\mathrm{pH}$-values and cation concentrations have to be considered due to their influence on the amount and mineralogical type of precipitates and therefore on the method used for selective P-recovery in the future. In view of a potential application of simultaneous N\&P sorption in wastewater treatment, the fixation of the precipitated CaP-phases to the zeolites surface is a major benefit in order to selectively recover phosphorous and avoid the need for subsequent filtration of fine-grained precipitates.

Acknowledgements The authors thank Maik Zimmermann for operational support during EPMA studies. Daniel Kiener is thanked for giving access to the FEG-SEM facilities at Erich 
Schmid Institute of Material Sciences. Johann G. Raith is gratefully acknowledged for his support.

Author Contribution Conceptualization, K.S. and M.E.; methodology, K.S.; investigation, K.S.; resources, M.E.; writing-original draft preparation, K.S. and M.E.; writing-review and editing, M.E; visualization, K.S.; supervision and project administration, M.E.; funding acquisition, M.E. and K.S.

Funding Open access funding provided by Montanuniversität Leoben. This research was funded by the Austrian Research Promotion Agency (FFG), project "ReNOx 2.0," grant number 864876 .

Availability of Data and Materials The authors declare that all data and materials support their published claims and comply with field standards.

Code Availability Not applicable.

\section{Declarations}

Ethics Approval Not applicable. No animal or human participants.

Consent to Participate Not applicable. No animal or client participants.

Consent for Publication Not applicable. No individual person's data in any form.

Conflict of Interest The authors declare no competing interests.

Open Access This article is licensed under a Creative Commons Attribution 4.0 International License, which permits use, sharing, adaptation, distribution and reproduction in any medium or format, as long as you give appropriate credit to the original author(s) and the source, provide a link to the Creative Commons licence, and indicate if changes were made. The images or other third party material in this article are included in the article's Creative Commons licence, unless indicated otherwise in a credit line to the material. If material is not included in the article's Creative Commons licence and your intended use is not permitted by statutory regulation or exceeds the permitted use, you will need to obtain permission directly from the copyright holder. To view a copy of this licence, visit http://creativecommons.org/licenses/by/4.0/.

\section{References}

Alshameri, A., Ibrahim, A., Assabri, A., Lei, X., Wang, H., \& Yan, C. (2014a). The investigation into the ammonium removal performance of Yemeni natural zeolite: Modification, ion exchange mechanism, and thermodynamics.
Powder Technology, 258, 20-31. https://doi.org/10.1016/j. powtec.2014.02.063

Alshameri, A., Yan, C., \& Lei, X. (2014b). Enhancement of phosphate removal from water by $\mathrm{TiO} 2 / Y e m e n i$ natural zeolite: Preparation, characterization and thermodynamic. Microporous and Mesoporous Materials, 196, 145-157. https://doi.org/10.1016/j.micromeso.2014.05.008

Bundesministerium für Umwelt, Naturschutz und nukleare Sicherheit BMU (2017). Verordnung zur Neuordnung der Klärschlammverwertung. AbfKlärV.

Choi, J.-W., Kwon, K.-S., Lee, S., An, B., Hong, S.-W., \& Lee, S.-H. (2014). Pilot-scale test for a phosphate treatment using sulfate-coated zeolite at a sewage disposal facility. Water, Air, \& Soil Pollution, 225,. https://doi.org/10.1007/ s11270-013-1835-3

Cordell, D., Drangert, J.-O., \& White, S. (2009). The story of phosphorus: Global food security and food for thought. Global Environmental Change, 19, 292-305. https://doi. org/10.1016/j.gloenvcha.2008.10.009

Daneshgar, S., Callegari, A., Capodaglio, A., \& Vaccari, D. (2018). The potential phosphorus crisis: Resource conservation and possible escape technologies: A review. Resources, 7, 37. https://doi.org/10.3390/resources7 020037

Ellersdorfer, M. (2018). The ion-exchanger-loop-stripping process: Ammonium recovery from sludge liquor using $\mathrm{NaCl}$-treated clinoptilolite and simultaneous air stripping. Water Science and Technology, 77, 695-705. https://doi. org/10.2166/wst.2017.561

European Commission. (2014). Communication from the commission to the European parliament, the council, the European economic and social committee and the committee of the regions on the review of the list of critical raw materials for the EU and the implementation of the raw materials initiative.

Fowler, D., Coyle, M., Skiba, U., Sutton, M., Cape, J., \& Reis, S., et al. (2013). The global nitrogen cycle in the twentyfirst century. Philosophical Transactions of the Royal Society of London. Series B, Biological sciences, 368, 20130164. https://doi.org/10.1098/rstb.2013.0164.

Gao, F., Xiao, L., \& Zhang, H. (2018). Potential of using synthesized nano-zeolite for ammonium and phosphate immobilization in dairy wastewater. The Journal of Dairy Research, 85, 375-378. https://doi.org/10.1017/S0022 029918000560

Guaya, D., Valderrama, C., Farran, A., Armijos, C., \& Cortina, J. (2015a). Simultaneous phosphate and ammonium removal from aqueous solution by a hydrated aluminum oxide modified natural zeolite. Chemical Engineering Journal, 271, 204-213. https://doi.org/10.1016/j.cej.2015. 03.003

Guaya, D., Valderrama, C., Farran, A., \& Cortina, J. (2015b). Modification of a natural zeolite with Fe(III) for simultaneous phosphate and ammonium removal from aqueous solutions. Journal of Chemical Technology \& Biotechnology, 91, 1737-1746. https://doi.org/10.1002/jctb.4763

He, Y., Lin, H., Dong, Y., Liu, Q., \& Wang, L. (2016). Simultaneous removal of phosphate and ammonium using saltthermal-activated and lanthanum-doped zeolite: Fixedbed column and mechanism study. Desalination and 
Water Treatment, 57, 27279-27293. https://doi.org/10. 1080/19443994.2016.1166459

Hermassi, M., Valderrama, C., Moreno, N., Font, O., Querol, X., Batis, N. H., \& Cortina, J. L. (2016). Powdered Caactivated zeolite for phosphate removal from treated waste-water. Journal of Chemical Technology \& Biotechnology, 91, 1962-1971. https://doi.org/10.1002/jctb.4867

Hermassi, M., Dosta, J., Valderrama, C., Licon, E., Moreno, N., Querol, X., Batis, N. H., \& Cortina, J. L. (2018). Simultaneous ammonium and phosphate recovery and stabilization from urban sewage sludge anaerobic digestates using reactive sorbents. The Science of the Total Environment, 630, 781-789. https://doi.org/10.1016/j.scitotenv. 2018.02.243

Hermassi, M., Valderrama, C., Font, O., Moreno, N., Querol, X., Batis, N. H., \& Cortina, J. L. (2020). Phosphate recovery from aqueous solution by K-zeolite synthesized from fly ash for subsequent valorisation as slow release fertilizer. The Science of the Total Environment, 731, 139002. https://doi.org/10.1016/j.scitotenv.2020.139002

Huo, H., Lin, H., Dong, Y., Cheng, H., Wang, H., \& Cao, L. (2012). Ammonia-nitrogen and phosphates sorption from simulated reclaimed waters by modified clinoptilolite. Journal of Hazardous Materials, 229-230, 292-297. https://doi.org/10.1016/j.jhazmat.2012.06.001

Jiang, C., Jia, L., He, Y., Zhang, B., Kirumba, G., \& Xie, J. (2013). Adsorptive removal of phosphorus from aqueous solution using sponge iron and zeolite. Journal of Colloid and Interface Science, 402, 246-252. https://doi.org/10. 1016/j.jcis.2013.03.057

Jiménez-Cedillo, M., Olguín, M., Fall, C., \& Colín, A. (2011). Adsorption capacity of iron- or iron-manganese-modified zeolite-rich tuffs for $\mathrm{As}(\mathrm{III})$ and $\mathrm{As}(\mathrm{V})$ water pollutants. Applied Clay Science, 54, 206-216. https://doi.org/10. 1016/j.clay.2011.09.004

Kok, D.-J., Pande, S., van Lier, J., Ortigara, A., Savenije, H., \& Uhlenbrook, S. (2018). Global phosphorus recovery from wastewater for agricultural reuse. Hydrology and Earth System Sciences, 22, 5781-5799. https://doi.org/10.5194/ hess-22-5781-2018

Law, K., \& Pagilla, K. (2018). Phosphorus recovery by methods beyond struvite precipitation. Water Environment Research, 90, 840-850. https://doi.org/10.2175/10614 3017X15131012188006

Li, B., Ning, P., Chen, Y.-B., Deng, C.-L., \& Jiang, Z. (2005). Nitrogen and phosphate removal by activated zeolite with lanthana. Wuhan Ligong Daxue Xuebao/journal of Wuhan University of Technology, 27, 56-59.

Li, B., Lu, X., Ning, P., \& Yang, Y. (2009). Nitrogen and phosphate removal by zeolite-rare earth adsorbents, 2009 International Conference on Environmental Science and Information Application Technology, ESIAT (pp. 599-602).

Malekian, R., Abedi-Koupai, J., Eslamian, S., Mousavi, S., Abbaspour, K., \& Afyuni, M. (2011). Ion-exchange process for ammonium removal and release using natural Iranian zeolite. Applied Clay Science, 51, 323-329. https:// doi.org/10.1016/j.clay.2010.12.020

Mitrogiannis, D., Psychoyou, M., Baziotis, I., Inglezakis, V., Koukouzas, N., Tsoukalas, N., Palles, D., Kamitsos, E., Oikonomou, G., \& Markou, G. (2017). Removal of phosphate from aqueous solutions by adsorption onto $\mathrm{Ca}(\mathrm{OH})_{2}$ treated natural clinoptilolite. Chemical Engineering Journal, 320, 510-522. https://doi.org/10.1016/j.cej.2017.03. 063

Mitrogiannis, D., Psychoyou, M., Koukouzas, N., Tsoukalas, N., Palles, D., Kamitsos, E., Pantazidis, A., Oikonomou, G., \& Baziotis, I. (2018). Phosphate recovery from real fresh urine by $\mathrm{Ca}(\mathrm{OH})_{2}$ treated natural zeolite. Chemical Engineering Journal, 347, 618-630. https://doi.org/10. 1016/j.cej.2018.04.102

Mitrogiannis, D., Psychoyou, M., Kornaros, M., Tsigkou, K., Brulé, M., Koukouzas, N., et al. (2020). Calcium-modified clinoptilolite as a recovery medium of phosphate and potassium from anaerobically digested olive mill wastewater. Environmental Science and Pollution Research International, 27, 2977-2991. https://doi.org/10.1007/ s11356-019-07212-5

Ning, P., Bart, H.-J., Li, B., Lu, X., \& Zhang, Y. (2008). Phosphate removal from wastewater by model-La(III) zeolite adsorbents. Journal of Environmental Sciences, 20, 670 674. https://doi.org/10.1016/S1001-0742(08)62111-7

Ostrooumov, M., Cappelletti, P., \& de'Gennaro, R. (2012). Mineralogical study of zeolite from New Mexican deposits (Cuitzeo area, Michoacan, Mexico). Applied Clay Science, 55, 27-35. https://doi.org/10.1016/j.clay.2011.09. 011

Salam, M., Mokhtar, M., Albukhari, S., Baamer, D., Palmisano, L., AlHammadi, A., \& Abukhadra, M. R. (2021). Synthesis of zeolite/geopolymer composite for enhanced sequestration of phosphate $\left(\mathrm{PO}_{4}^{3-}\right)$ and ammonium $\left(\mathrm{NH}_{4}{ }^{+}\right)$ ions; Equilibrium properties and realistic study. Journal of Environmental Management, 300, 113723. https://doi.org/ 10.1016/j.jenvman.2021.113723

Sang, W., Mei, L., Hao, S., Li, D., Li, X., Zhang, Q., Jin, X., \& Li, C. (2020). Na@La-modified zeolite particles for simultaneous removal of ammonia nitrogen and phosphate from rejected water: Performance and mechanism. Water Science and Technology: A Journal of the International Association on Water Pollution Research, 82, 2975-2989. https://doi.org/10.2166/wst.2020.541

Schick, J., Caullet, P., Paillaud, J.-L., Patarin, J., Freitag, S., \& Mangold-Callarec, C. (2012). Phosphate uptake from water on a surfactant-modified zeolite and Ca-zeolites. Journal of Porous Materials, 19, 405-414. https://doi.org/ 10.1007/s10934-011-9488-3

Simsek, E., Özdemir, E., \& Beker, U. (2013). Zeolite supported mono- and bimetallic oxides: Promising adsorbents for removal of $\mathrm{As}(\mathrm{V})$ in aqueous solutions. Chemical Engineering Journal, 220, 402-411. https://doi.org/10.1016/j. cej.2013.01.070

Sun, Y., Lin, J., Huang, H., Zhang, W., \& Ma, D. (2011). Simultaneous removal of ammonium and phosphate from aqueous solution by calcium chloride-modified zeolite. Advanced Materials Research, 356-360, 1581-1585. https://doi.org/10.4028/www.scientific.net/AMR.356-360. 1581

Vollprecht, D., Frühauf, S., Stocker, K., \& Ellersdorfer, M. (2019). Ammonium sorption from landfill leachates using natural and modified zeolites: Pre-tests for a novel application of the ion exchanger loop stripping process. Minerals, 9, 471. https://doi.org/10.3390/min9080471 
Vučić, V., Süring, C., Harms, H., Müller, S., \& Günther, S. (2021). A framework for P-cycle assessment in wastewater treatment plants. Science of the Total Environment, 760, 143392. https://doi.org/10.1016/j.scitotenv.2020. 143392

Wan, C., Ding, S., Zhang, C., Tan, X., Zou, W., Liu, X., \& Yang, X. (2017). Simultaneous recovery of nitrogen and phosphorus from sludge fermentation liquid by zeolite adsorption: Mechanism and application. Separation and Purification Technology, 180, 1-12. https://doi.org/10. 1016/j.seppur.2017.02.031

Xu, R., Lyu, T., Wang, L., Yuan, Y., Zhang, M., Cooper, M., Mortimer, R. J. G., Yang, Q., \& Pan, G. (2022). Utilization of coal fly ash waste for effective recapture of phosphorus from waters. Chemosphere, 287, 132431. https:// doi.org/10.1016/j.chemosphere.2021.132431

Yin, H., \& Kong, M. (2014). Simultaneous removal of ammonium and phosphate from eutrophic waters using natural calcium-rich attapulgite-based versatile adsorbent. Desalination, 351, 128-137. https://doi.org/10.1016/j.desal. 2014.07.029

You, X., Valderrama, C., \& Cortina, J. (2017). Simultaneous recovery of ammonium and phosphate from simulated treated wastewater effluents by activated calcium and magnesium zeolites. Journal of Chemical Technology \& Biotechnology, 92, 2400-2409. https://doi.org/10.1002/ jctb.5249

Zhang, B., Wu, D., Wang, C., He, S., Zhang, Z., \& Kong, H. (2007). Simultaneous removal of ammonium and phosphate by zeolite synthesized from coal fly ash as influenced by acid treatment. Journal of Environmental Sciences, 19, 540-545. https://doi.org/10.1016/S10010742(07)60090-4

Zhang, M., Zhang, H., Xu, D., Han, L., Niu, D., Tian, B., et al. (2011). Removal of ammonium from aqueous solutions using zeolite synthesized from fly ash by a fusion method. Desalination, 271, 111-121. https://doi.org/10.1016/j. desal.2010.12.021

Publisher's Note Springer Nature remains neutral with regard to jurisdictional claims in published maps and institutional affiliations. 